\title{
Investigating the strategic antecedents of agility in humanitarian logistics
}

\author{
Cécile L'Hermitte, Benjamin Brooks, Marcus Bowles, and Peter H. Tatham ${ }^{1}$
}

This study investigates the strategic antecedents of operational agility in humanitarian logistics. It began by identifying the particular actions to be taken at the strategic level of a humanitarian organisation to support field-level agility. Next, quantitative data $(n=59)$ were collected on four strategic-level capabilities (being purposeful, action-focused, collaborative, and learning-oriented) and on operational agility (field responsiveness and flexibility). Using a quantitative analysis, the study tested the relationship between organisational capacity building and operational agility and found that the four strategic-level capabilities are fundamental building blocks of agility. Collectively they account for 52 per cent of the ability of humanitarian logisticians to deal with ongoing changes and disruptions in the field. This study emphasises the need for researchers and practitioners to embrace a broader perspective of agility in humanitarian logistics. In addition, it highlights the inherently strategic nature of agility, the development of which involves focusing simultaneously on multiple drivers.

Keywords: agility, humanitarian logistics, humanitarian supply chain, organisational capacity building, risk management, strategic capabilities

\section{Introduction}

As humanitarian organisations operate in very volatile and dynamic environments, they must be able to cope with the uncertainty, risk, complexity, and even unknown unknowns (truly unforeseeable events) that are inherent in field operations. Agility is the ability to respond to any of these challenges (Charles, Lauras, and Van Wassenhove, 20IO). In the humanitarian logistics context, however, dealing with changes and disruptions along the supply chain often is associated with field-level creative solutions (WFP, 2013a, 20I3c, 20I4). While ad hoc problem-solving is, undoubtedly, valuable to cope with unpredictable events (Jahre, Jensen, and Listou, 2009), the general humanitarian literature indicates that a structured organisational approach is the key to successful risk management (Kent, 20I I; Metcalfe, Martin, Pantuliano, 20I I). Similarly, in the more specialised humanitarian logistics literature, emergent research recognises that a systematic approach is essential to the development of agility (Tatham and Christopher, 20I4; Tomasini and Van Wassenhove, 2009; Tatham and Christopher, 2014; L'Hermitte et al., 20I5). To date, though, these studies remain conceptual and the impact of strategic factors on the ability of humanitarian organisations to respond appropriately to operational disruptions has not been measured.

This study investigates the strategic antecedents of agility in the humanitarian logistics sector and tests the extent to which a number of strategic elements (collectively referred to as organisational capacity building) influence the ability of humanitarian 
organisations to overcome the ongoing changes and multiple disruptions encountered in the field. In other words, it explores what should be done at the strategic level of a humanitarian organisation to enhance responsiveness and flexibility in the field and, thus, to prevent anticipated and unexpected disruptive events from negatively affecting humanitarian deliveries. By doing so, it addresses the following research question:

To what extent does organisational capacity building impact on operational agility in the humanitarian logistics context?

A quantitative approach was selected to measure this relationship. In particular, survey data were collected and analysed using structural equation modelling, which is suitable for testing conceptual models including latent (non-observed) variables (Byrne, 20I0). This research demonstrates that there is a direct and significant relationship between organisational capacity building and operational agility, and it explains how humanitarian organisations can create agility by building organisational capacity. As a result, this study extends the scope of the concept of agility in humanitarian logistics and shifts the spotlight in relation to this concept from operational considerations to strategic ones. In doing so, the paper addresses a significant limitation in the humanitarian logistics literature: its predominant focus on operational matters.

The remainder of this paper is structured as follows. Section two presents an overview of the strategic and operational components of agility, as well as the model postulated in this research. Section three discusses the methodological aspects of the work. Section four identifies the specific strategic decision-making areas that are most associated with operational agility and, on this basis, develops the measurement scales used in the study. Section five employs structural equation modelling to test the hypothesised relationships, before considering the results of this analysis and the limitations of the research. Section six assesses the study's implications for research and practitioners.

\section{The concept of agility in humanitarian logistics}

\section{The strategic and operational components of agility}

Agility is represented here as a multidimensional concept that is composed of both strategic and operational components. At the strategic level, the study draws on the work of L'Hermitte et al. (2015) who reviewed the literature on agility in a business context and, via this analysis, pinpointed four strategic-level agility capabilities relevant to the field of humanitarian logistics. However, these dimensions and their impacts have not been tested quantitatively to date. The strategic-level agility capabilities include:

- being purposeful (the capacity to maintain a clear direction for humanitarian action);

- being action-focused (the capacity to build readiness and marshal the organisation to respond to the risks, uncertainties, and opportunities encountered along humanitarian supply chains);

- being collaborative (the capacity to build and sustain relationships inside and outside the humanitarian organisation to solve problems collaboratively); and 
- being learning-oriented (the capacity to identify and capture past field experiences, to share them across operations, and to turn them into improved practice).

At the operational level, the components of agility include responsiveness and flexibility (L'Hermitte et al., 20I5). Owing to the ongoing uncertainty prevailing in the humanitarian environment, responsiveness and flexibility are repeatedly highlighted as two essential objectives pursued by agile humanitarian organisations (see, for example, Charles, Lauras, and Van Wassenhove, 20I0; McGuire, 20I I). Responsiveness is the ability to sense and spot rapidly operational risks and opportunities along the supply chain, as well as to draw up swiftly a suitable response. Thus, a responsive organisation understands quickly the nature, extent, and effect of the forces disrupting supply chain operations and makes speedy decisions to manage them.

A flexible organisation moves speedily from identifying risks/opportunities and from planning a response to the execution phase, that is, to taking action as necessary to prevent the disruptive forces from impacting negatively on humanitarian deliveries or to seize the possibilities arising along the supply chain. Flexibility is defined, therefore, as the ability to act in a timely manner and to adjust rapidly logistics operations.

Most importantly, responsiveness and flexibility complement each other. In other words, an organisation cannot be agile and quickly overcome contingencies without being both responsive and flexible (Shahabi, Cusumano, and Sohonie, 2015). Hence this study considers responsiveness and flexibility together and, within the framework of this paper, integrates them into the concept of operational agility.

\section{Hypothesised relationships}

As highlighted in the broader management literature (see, for example, Goldman and Nagel, I993; Redding and Catalanello, I994; Dove, I996; Roth, I996; Gunasekaran, I998; McCann and Selsky, 20I2), agility stems from the interactions between a number of mutually reinforcing factors that, taken separately, are not sufficient. This paper contends, therefore, that the four strategic-level capabilities (see above) are not only closely related to each other, but also that they form an integrated whole that collectively reflects what should be done at the strategic level of an organisation to enable fieldworkers to overcome disruptions or to seize opportunities. Consequently, as illustrated in Figure I, a latent variable (or factor) called organisational capacity building is modelled, and it is anticipated that this will account for the shared variance among the four strategic-level capabilities. On this basis, this study postulates that:

The four strategic-level agility capabilities collectively reflect organisational capacity building (HI).

The second underlying argument of this paper is that organisational capacity building (that is, being purposeful, action-focused, collaborative, and learning-oriented) impacts positively on operational agility. In particular, being purposeful enables an organisation to develop and maintain collective meaning and a strong identity that steer people towards a defined course of action and provide a clear direction to their work (Handler Chayes, Chayes, and Raach, I997; Appelo, 20 I ; McCann and Selsky, 
Figure 1. Theoretical model of agility in humanitarian logistics

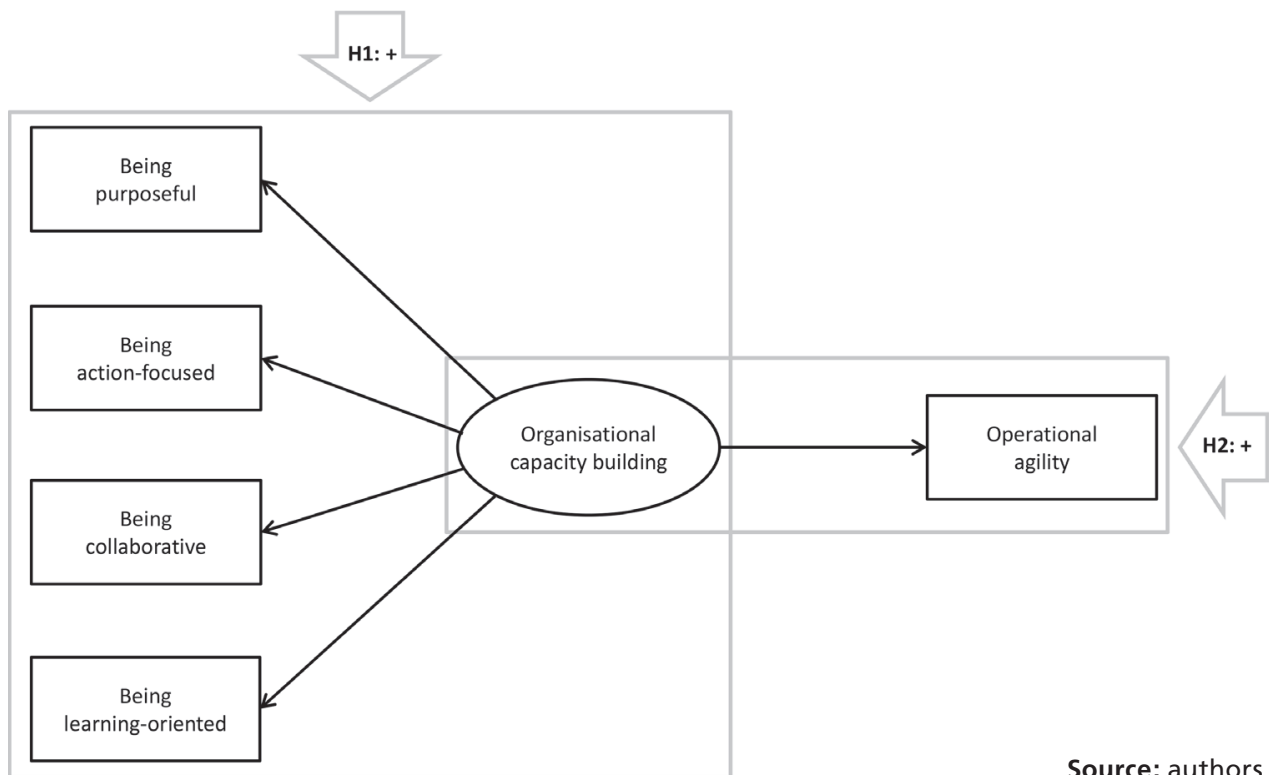

20I2). In the humanitarian context, this course of action is guided by the core values and primary motivations of humanitarian organisations: saving lives and alleviating human suffering (Australian Civil-Military Centre, 2OI2). For these reasons it is expected that being purposeful positively affects operational agility.

An action-focused organisation provides operational staff with a number of tools that enable them to deal appropriately with field contingencies. For instance, fieldworkers need to have access to up-to-date information, to be appropriately qualified, to have the right skills, and to be able to rely on procedures and protocols that support swift action. All of these elements increase the ability of an organisation to manage field contingencies (Gatignon, Van Wassenhove, and Charles, 20Iо; Kruke and Olsen, 2OI2; Seal and Bailey, 2OI3). The study suggests, therefore, that being action-focused enhances the agility of field operations.

Internal and external collaboration have been recognised as essential components of supply chain agility in the business context. For example, according to Christopher (2OII), collaboration enhances supply chain synchronisation, process alignment, and streamlined deliveries. In the humanitarian context, internal integration (that is, across functions and organisational levels such as headquarters, country offices, and frontline staff) and external relationships (that is, with other humanitarian organisations, local and national authorities, and commercial and military entities) enable humanitarian organisations to deploy swiftly the resources needed, to provide timely logistics services, and to increase the speed of aid distribution (Logistics Cluster, 20I3; Featherstone, 20I4). Internal and external relationships also enable humanitarian organisations to adjust rapidly their operations to prevent disruptive circumstances from impacting negatively on the distribution of humanitarian aid (WFP, 2013b). So, being collaborative (internally and externally) is expected to contribute to operational agility. 
Learning-oriented organisations support innovation at the field level (for instance, non-routine problem-solving), capture these experiences, share them across operations, evaluate actions on an ongoing basis, and engage in a process of continuous improvement. This not only helps field staff to speed up their decision-making, but also enhances the organisation's anticipatory and adaptive capacity (Ramalingam, Scriven, and Foley, 2009). Being learning-oriented is expected, therefore, to enhance the agility of field operations.

Following on from the above discussions, this study suggests that organisational capacity building (which encompasses the four strategic-level capabilities) increases field responsiveness and flexibility. Consequently, it hypothesises that:

\section{Organisational capacity building impacts positively on operational agility $\left(\mathrm{H}_{2}\right)$.}

Figure I represents the postulated model. It shows not only that the four strategiclevel capabilities reflect organisational capacity building, but also the positive effect of organisational capacity building on operational agility. In line with the standard symbol notation used in structural equation modelling (Hair et al., 2006; Byrne, 20IO), the arrows leading from the factor to the four strategic-level indicators represent the factor loadings (that is, the proportion of variance in each indicator explained by organisational capacity building), and the arrow leading from the factor to the outcome indicator represents the path coefficient (that is, the direct effect of organisational capacity building on operational agility).

\section{Methodological considerations}

Based on the model presented in the previous section, five constructs need to be measured: (i) four predictors: being purposeful; being action-focused; being collaborative; and being learning-oriented; and (ii) one outcome variable: operational agility.

To achieve this, multi-item measures were used. As argued by Churchill (I979), multi-item measures represent better the constructs and enable researchers to consider their multiple facets. In addition, multi-item indicators improve the reliability (consistency) as well as the validity of measurement, and increase the level of distinction among cases (that is, generate greater variability) (Warner, 20I3).

As recommended and/or performed in the academic literature (see, for example, Eisenhardt, I989; Vázquez-Bustelo, Avella, and Fernández, 2007), a step-by-step process was followed to identify the scale items used to delineate the constructs of this research and to collect data. Initially, scale items were derived from previous research, in line with the recommendation of Lounsbury, Gibson, and Saudargas (2006). In particular, the study drew on the comprehensive review of the literature on agility undertaken by L'Hermitte et al. (20I5). Since they argue that leaders should develop simultaneously the agility capabilities across organisational levels, this research framed the scales of the four strategic-level capabilities in such a way as to match the different levels of an organisation (that is, individual, team, central, and supply chain network). By doing so, it aimed to achieve substantial coverage of the various dimensions 
associated with a particular construct and, thereby, increase the content validity of the scales (Warner, 2013).

The initial list of items to be measured was refined subsequently and/or items were reformulated on the basis of a content analysis of 29 interviews, each approximately 40 minutes in length, which took place in June 2014 at the headquarters of the United Nations World Food Programme (WFP) in Rome, Italy. The participants were selected on the advice of WFP's logistics senior management based on their extensive experience (current or former) of humanitarian logistics (more than Io years for 27 of them), as well as their expected insights in relation to the concept of agility. At the time of the interviews, 24 participants held positions in WFP's logistics division and 5 in other departments (policy, programme and innovation, information technology, procurement, and emergency preparedness). The job titles of the interviewees were varied but included emergency preparedness and response officer, head of logistics, logistics coordinator, logistics cluster officer, logistics officer, as well as director or deputy director.

Consistent with the multi-level approach to agility adopted in this research, the interview participants were WFP staff members working at various levels of the organisation, ranging from the operational to the strategic level. In particular, nine of the interviewees were current fieldworkers visiting headquarters or former fieldworkers who were interviewed in relation to their previous field experience. These fieldworkers were involved in an assortment of operations, including Afghanistan, Burkina Faso, Democratic Republic of the Congo, Pakistan, and Senegal. Among the other interview participants, 9 were working at WFP headquarters in Rome in functional positions (such as fleet management, information management, and shipping), and I I were working in middle or senior managerial positions.

Table I presents the interview questionnaire, ${ }^{2}$ whereas Table 2 presents the resultant 46 items designed to serve as a basis for the collection of quantitative data.

\section{Table 1. Interview questions}

\begin{tabular}{|l|l|}
\hline Topic covered & Questions \\
\hline General questions & $\begin{array}{l}\text { When people talk about agility and about making WFP a more agile organisation, what do they mean? } \\
\text { What actions are taken at the strategic level of the organisation to support the agility of logistics } \\
\text { operations? }\end{array}$ \\
\hline Being purposeful & $\begin{array}{l}\text { In your opinion, is WFP an organisation with a clear purpose? Why? } \\
\text { In your opinion, does a clear purpose lead to more responsiveness and flexibility in the field? } \\
\text { If yes, how? If no, why? }\end{array}$ \\
\hline Being action-focused & What does WFP do to ensure that fieldworkers are able to take appropriate action on the ground? \\
\hline Being collaborative & $\begin{array}{l}\text { Which working relationships (internal and external) are essential for fieldworkers to achieve } \\
\text { responsiveness and flexibility on the ground? Why? }\end{array}$ \\
\hline Being learning-oriented & $\begin{array}{l}\text { Are there formal mechanisms in place at WFP to capture and to share learning from past opera- } \\
\text { tional failures and successes? If yes, which ones? If no, why? } \\
\text { In your opinion, does organisational learning lead to more responsiveness and flexibility in the } \\
\text { field? If yes, how? If no, why? }\end{array}$
\end{tabular}

Source: authors. 
Table 2. Constructs, associated item measures, and related literature

\begin{tabular}{|c|c|c|c|c|}
\hline Construct & Code & Item measure & $\begin{array}{l}\text { Organisational } \\
\text { level }\end{array}$ & Main source \\
\hline \multirow{7}{*}{$\begin{array}{l}\text { Being } \\
\text { purposeful }\end{array}$} & P1 & My organisation has a clear purpose. & Central & McCann and Selsky (2012) \\
\hline & P2 & $\begin{array}{l}\text { My organisation enhances its consistency of } \\
\text { purpose by aligning goals and objectives across } \\
\text { all levels. }\end{array}$ & Central & McCann and Selsky (2012) \\
\hline & P3 & $\begin{array}{l}\text { My organisation's processes and procedures } \\
\text { are set up to achieve the overall purpose. }\end{array}$ & Central & McCann and Selsky (2012) \\
\hline & P4 & I fully identify with my organisation's purpose. & Individual & McCann and Selsky (2012) \\
\hline & P5 & $\begin{array}{l}\text { My actions are guided by my organisation's } \\
\text { purpose. }\end{array}$ & Individual & McCann and Selsky (2012) \\
\hline & P6 & $\begin{array}{l}\text { My team/group clearly understands what has } \\
\text { to be done to fulfil the organisation's purpose. }\end{array}$ & Team & Appelo (2011) \\
\hline & P7 & $\begin{array}{l}\text { Partners across the supply chain share a sense } \\
\text { of common purpose. }\end{array}$ & $\begin{array}{l}\text { Supply chain } \\
\text { network }\end{array}$ & McCann and Selsky (2012) \\
\hline \multirow{12}{*}{$\begin{array}{l}\text { Being } \\
\text { action- } \\
\text { focused }\end{array}$} & A1 & $\begin{array}{l}\text { I have the skills needed to meet the require- } \\
\text { ments of my position. }\end{array}$ & Individual & McCann and Selsky (2012) \\
\hline & $A 2$ & $\begin{array}{l}\text { I feel confident in my ability to take the initia- } \\
\text { tive as necessary. }\end{array}$ & Individual & McCann and Selsky (2012) \\
\hline & A3 & My team/group has the necessary resources. & Team & McCann and Selsky (2012) \\
\hline & A4 & $\begin{array}{l}\text { My team/group is provided with suitable } \\
\text { processes and procedures for dealing with } \\
\text { common situations. }\end{array}$ & Team & Interviews \\
\hline & A5 & $\begin{array}{l}\text { My team/group is authorised to adapt pro- } \\
\text { cesses and procedures when necessary. }\end{array}$ & Team & Interviews \\
\hline & A6 & $\begin{array}{l}\text { My organisation has an extensive field pres- } \\
\text { ence (including offices in remote areas). }\end{array}$ & Central & Interviews \\
\hline & A7 & $\begin{array}{l}\text { My organisation has short and rapid decision- } \\
\text { making lines and approval protocols. }\end{array}$ & Central & McCann and Selsky (2012) \\
\hline & A8 & $\begin{array}{l}\text { My organisation delegates authority and } \\
\text { responsibilities to support action. }\end{array}$ & Central & Appelo (2011) \\
\hline & A9 & $\begin{array}{l}\text { My organisation has effective leaders in place } \\
\text { who drive action. }\end{array}$ & Central & Interviews \\
\hline & A10 & $\begin{array}{l}\text { My organisation makes accurate logistics } \\
\text { information available (e.g. track-and-trace } \\
\text { information, availability of resources, etc.). }\end{array}$ & Central & Handfield and Nichols (2002) \\
\hline & A11 & $\begin{array}{l}\text { My organisation disseminates risk-related } \\
\text { information to assist decision-making in } \\
\text { uncertain situations (e.g. political or } \\
\text { weather risks). }\end{array}$ & Central & Interviews \\
\hline & $\mathrm{A} 12$ & $\begin{array}{l}\text { My organisation disseminates demand-related } \\
\text { information (e.g. what is needed, in which } \\
\text { quantities, when, where) in a timely manner. }\end{array}$ & Central & Christopher (2011) \\
\hline
\end{tabular}




\begin{tabular}{|c|c|c|c|c|}
\hline Construct & Code & Item measure & $\begin{array}{l}\text { Organisational } \\
\text { level }\end{array}$ & Main source \\
\hline \multirow{3}{*}{$\begin{array}{l}\text { Being } \\
\text { action- } \\
\text { focused }\end{array}$} & A13 & $\begin{array}{l}\text { My organisation provides the right information } \\
\text { to the right people at the right time. }\end{array}$ & Central & McCann and Selsky (2012) \\
\hline & A14 & $\begin{array}{l}\text { Partners across the supply chain actively } \\
\text { engage in information-sharing (e.g. logistics } \\
\text { data, predictive analysis, etc.). }\end{array}$ & $\begin{array}{l}\text { Supply chain } \\
\text { network }\end{array}$ & McCann and Selsky (2012) \\
\hline & A15 & $\begin{array}{l}\text { Partners across the supply chain develop } \\
\text { consistent policies and procedures to support } \\
\text { their action. }\end{array}$ & $\begin{array}{l}\text { Supply chain } \\
\text { network }\end{array}$ & Christopher (2011) \\
\hline \multirow[t]{9}{*}{$\begin{array}{l}\text { Being } \\
\text { collaborative }\end{array}$} & C1 & $\begin{array}{l}\text { I maintain positive and active relationships } \\
\text { with others within the organisation. }\end{array}$ & Individual & McCann and Selsky (2012) \\
\hline & C2 & $\begin{array}{l}\text { I maintain positive and active relationships } \\
\text { with people outside the organisation. }\end{array}$ & Individual & McCann and Selsky (2012) \\
\hline & $\mathrm{C} 3$ & $\begin{array}{l}\text { My team/group is fully aware of the expertise } \\
\text { of other units/divisions within the organisation. }\end{array}$ & Team & Weick and Sutcliffe (2001) \\
\hline & C4 & $\begin{array}{l}\text { My team/group actively collaborates with } \\
\text { other units/divisions within the organisation } \\
\text { to solve problems. }\end{array}$ & Team & McCann and Selsky (2012) \\
\hline & C5 & $\begin{array}{l}\text { My team/group actively collaborates with } \\
\text { others outside the organisation to solve } \\
\text { problems. }\end{array}$ & Team & McCann and Selsky (2012) \\
\hline & C6 & $\begin{array}{l}\text { My organisation has mechanisms in place to } \\
\text { support trust and coordination between the } \\
\text { different units/divisions. }\end{array}$ & Central & McCann and Selsky (2012) \\
\hline & $\mathrm{C7}$ & $\begin{array}{l}\text { My organisation eliminates functional silos } \\
\text { by supporting the integration of the different } \\
\text { parts of the organisation. }\end{array}$ & Central & Appelo (2011) \\
\hline & C8 & $\begin{array}{l}\text { Partners across the supply chain have a clear } \\
\text { understanding of the role and competencies } \\
\text { of the different parties with which they are } \\
\text { working. }\end{array}$ & $\begin{array}{l}\text { Supply chain } \\
\text { network }\end{array}$ & McCann and Selsky (2012) \\
\hline & C9 & $\begin{array}{l}\text { Partners across the supply chain work together } \\
\text { to solve problems. }\end{array}$ & $\begin{array}{l}\text { Supply chain } \\
\text { network }\end{array}$ & McCann and Selsky (2012) \\
\hline \multirow{5}{*}{$\begin{array}{l}\text { Being } \\
\text { learning- } \\
\text { oriented }\end{array}$} & L1 & $\begin{array}{l}\text { I am committed to active learning and self- } \\
\text { development. }\end{array}$ & Individual & McCann and Selsky (2012) \\
\hline & L2 & $\begin{array}{l}\text { I generate new insights and share information } \\
\text { with others in the team/group. }\end{array}$ & Individual & $\begin{array}{l}\text { Bontis, Crossan, and Hulland } \\
(2002)\end{array}$ \\
\hline & L3 & $\begin{array}{l}\text { My team/group continuously learns from com- } \\
\text { municating with other units/divisions. }\end{array}$ & Team & McCann and Selsky (2012) \\
\hline & L4 & $\begin{array}{l}\text { My team/group reflects on past experiences } \\
\text { and generates its own procedures based on } \\
\text { best practices. }\end{array}$ & Team & Redding and Catalanello (1994) \\
\hline & L5 & $\begin{array}{l}\text { My organisation has mechanisms in place for } \\
\text { identifying lessons from past operational } \\
\text { successes and failures. }\end{array}$ & Central & Garvin (1993) \\
\hline
\end{tabular}




\begin{tabular}{|c|c|c|c|c|}
\hline Construct & Code & Item measure & $\begin{array}{l}\text { Organisational } \\
\text { level }\end{array}$ & Main source \\
\hline \multirow[t]{4}{*}{$\begin{array}{l}\text { Being } \\
\text { learning- } \\
\text { oriented }\end{array}$} & L6 & $\begin{array}{l}\text { My organisation translates the lessons from } \\
\text { past experiences into improved and more } \\
\text { relevant processes and practices. }\end{array}$ & Central & Redding and Catalanello (1994) \\
\hline & L7 & $\begin{array}{l}\text { My organisation shares best practices through- } \\
\text { out the organisation and across operations. }\end{array}$ & Central & $\begin{array}{l}\text { Ramalingam, Scriven, and } \\
\text { Foley (2009) }\end{array}$ \\
\hline & L8 & $\begin{array}{l}\text { Partners across the supply chain learn from } \\
\text { each other. }\end{array}$ & $\begin{array}{l}\text { Supply chain } \\
\text { network }\end{array}$ & McCann and Selsky (2012) \\
\hline & L9 & $\begin{array}{l}\text { Partners jointly evaluate their performance in } \\
\text { order to improve their future work. }\end{array}$ & $\begin{array}{l}\text { Supply chain } \\
\text { network }\end{array}$ & Interviews \\
\hline \multirow[t]{3}{*}{ Responsiveness } & R1 & $\begin{array}{l}\text { Ability to identify risks and opportunities along } \\
\text { the supply chain. }\end{array}$ & Operational & Manuj and Mentzer (2008) \\
\hline & R2 & $\begin{array}{l}\text { Ability to quickly respond to operational risks } \\
\text { and opportunities. }\end{array}$ & Operational & Manuj and Mentzer (2008) \\
\hline & R3 & Ability to make fast decisions. & Operational & Manuj and Mentzer (2008) \\
\hline \multirow[t]{3}{*}{ Flexibility } & F1 & $\begin{array}{l}\text { Ability to reconfigure transport operations } \\
\text { (e.g. to change transport modes or routes). }\end{array}$ & Operational & McGuire (2011) \\
\hline & F2 & $\begin{array}{l}\text { Ability to adapt the delivery terms (e.g. range } \\
\text { of products, volume, place, date, frequency). }\end{array}$ & Operational & $\begin{array}{l}\text { Charles, Lauras, and Van } \\
\text { Wassenhove (2010) }\end{array}$ \\
\hline & F3 & $\begin{array}{l}\text { Ability to adjust the network of partners } \\
\text { (e.g. suppliers of logistics services, military). }\end{array}$ & Operational & Chandra and Grabis (2007) \\
\hline
\end{tabular}

Source: authors.

To measure these items, data were collected through an online survey. The target population was humanitarian logistics practitioners with field experience. Participants were recruited with the help of WFP, the Humanitarian Emergency Logistics Professionals (HELP) Forum of the Chartered Institute of Logistics and Transport in the United Kingdom (CILT UK), and individual humanitarian logisticians, as well as by posting the survey link on the webpage of the Humanitarian Logistics Association's LinkedIn discussion group.

Participants were presented with the 46 aforementioned items to be measured on a five-point Likert scale. Their level of agreement with the 40 first items (those associated with the strategic-level capabilities) was gauged using the following rating scale: (I) strongly agree; (2) agree; (3) neither agree nor disagree; (4) disagree; and (5) strongly disagree. Their estimation of operational agility (the last six items) was determined using the following scale: (I) very good; (2) good; (3) neutral; (4) poor; and (5) very poor.

A total of 67 responses were collected between November 2014 and February 2015. Eight responses were excluded from the final analysis because the cases contained more than Io per cent of missing data (that is, more than four missing values); according to Bennett (200I), such cases may distort the results of the statistical analysis. The remaining 59 cases were explored by conducting the Missing Completely at Random (MCAR) data test provided by Little (I988). This indicated that approximately 0.7 per cent of 
the values were missing and that there was no evidence of a systematic pattern. Table 3 presents the descriptive statistics for the 46 items. In particular it includes information on the statistical dispersion of the data, that is, the range (the smallest and the largest values selected by the respondents), the mean (the average value), and the standard deviation (the average deviation from the mean) (Allen, Bennett, and Heritage, 20I4).

To analyse the collected data, the study tested the internal consistency of the scales and conducted a structural equation modelling analysis.

\section{Scale reliability and composite measures Operational agility}

Assessing the extent to which the items are linked to the underlying construct is essential to avoid measurement errors and to ensure that consistent results are generated (Warner, 20I3). Thus, the internal consistency of the scales was evaluated by conducting a reliability analysis that consisted of calculating the Cronbach's alpha estimates $(\alpha)$ and considering the corrected item-to-total statistics. The corrected itemto-total statistics gauge the level of correlation between each item and the sum of the remaining items included in the scale (Allen, Bennett, and Heritage, 20I4), and therefore are designed to determine which elements should be retained in or discarded from the scale (Lounsbury, Gibson, and Saudargas, 2006).

The resultant Cronbach's alpha value associated with operational agility ( $\alpha=$ o.829) exceeds the recommended level of 0.700 (Streiner, Norman, and Cairney,
Table 3. Descriptive statistics

\begin{tabular}{|c|c|c|c|}
\hline Code & Range & Mean & Standard deviation \\
\hline P1 & $1-3$ & 1.56 & .565 \\
\hline P2 & $1-4$ & 2.10 & .736 \\
\hline P3 & $1-4$ & 2.08 & .877 \\
\hline P4 & $1-4$ & 1.66 & .757 \\
\hline P5 & $1-4$ & 1.73 & .691 \\
\hline P6 & $1-4$ & 2.02 & .754 \\
\hline P7 & $1-5$ & 2.59 & .893 \\
\hline A1 & $1-3$ & 1.59 & .529 \\
\hline A2 & $1-2$ & 1.53 & .504 \\
\hline A3 & $1-5$ & 2.39 & .929 \\
\hline A4 & $1-5$ & 2.14 & .840 \\
\hline A5 & $1-5$ & 2.32 & .860 \\
\hline A6 & $1-4$ & 1.39 & .616 \\
\hline A7 & $1-5$ & 2.37 & 1.015 \\
\hline A8 & $1-5$ & 2.02 & .841 \\
\hline A9 & $1-5$ & 2.37 & .927 \\
\hline A10 & $1-5$ & 2.32 & .955 \\
\hline A11 & $1-4$ & 2.29 & .832 \\
\hline $\mathrm{A} 12$ & $1-5$ & 2.46 & .857 \\
\hline A13 & $1-5$ & 2.68 & .860 \\
\hline A14 & $1-5$ & 2.93 & 1.032 \\
\hline A15 & $1-5$ & 2.88 & .911 \\
\hline C1 & $1-2$ & 1.58 & .498 \\
\hline $\mathrm{C2}$ & $1-3$ & 1.78 & .559 \\
\hline C3 & $1-4$ & 2.37 & .849 \\
\hline C4 & $1-4$ & 1.98 & .601 \\
\hline C5 & $1-4$ & 2.12 & .672 \\
\hline C6 & $1-4$ & 2.49 & .878 \\
\hline C7 & $1-4$ & 2.92 & .836 \\
\hline C8 & $1-4$ & 2.86 & .899 \\
\hline C9 & $1-4$ & 2.61 & .743 \\
\hline L1 & $1-3$ & 1.56 & .565 \\
\hline L2 & $1-3$ & 1.68 & .539 \\
\hline L3 & $1-4$ & 2.14 & .601 \\
\hline L4 & $1-4$ & 2.02 & .682 \\
\hline L5 & $1-5$ & 2.36 & .924 \\
\hline L6 & $1-5$ & 2.80 & .943 \\
\hline L7 & $1-5$ & 2.64 & .961 \\
\hline L8 & $1-5$ & 2.76 & .916 \\
\hline L9 & $1-5$ & 3.05 & .818 \\
\hline R1 & $1-4$ & 2.00 & .830 \\
\hline R2 & $1-4$ & 1.88 & .790 \\
\hline R3 & $1-4$ & 1.98 & .881 \\
\hline F1 & $1-3$ & 1.76 & .652 \\
\hline F2 & $1-5$ & 2.07 & .828 \\
\hline F3 & $1-5$ & 2.12 & .911 \\
\hline
\end{tabular}

Source: authors. 
20I5). This value, indicating that 82.9 per cent of the variance is shared across the six items included in the scale, would not be higher if any of the six items comprising the scale were to be discarded. The corrected item-to-total correlation levels related to operational agility are also satisfactory (from 0.558 to 0.690 ), that is greater than 0.400 , as recommended by Lounsbury, Gibson, and Saudargas (2006). This confirms the reliability of the scale and supports the computation of a composite score for operational agility. Consequently, an aggregate of the six individual items included in the operational agility scale was produced.

\section{Levels of association between the strategic-level items and operational agility}

Since the strategic decision-making areas presented in Table 2 have not been tested empirically to date, the level of bivariate correlation between each of these elements and operational agility was considered by running a Spearman's rank correlation test. Doing so facilitated the identification of which items generate the highest levels of variability in relation to operational agility and, hence, the identification of which items are strongly associated with the outcome variable. Table 4 shows the levels of correlation between the 40 strategic-level items and operational agility.

To pinpoint the most statistically significant levels of bivariate correlation between these individual items and operational agility, the 22 items significant at the 0. or level $(\star \star)$ were selected. These items were used to compute the four strategic-level composite indicators. Since the 22 individual items showing significant correlation with operational agility

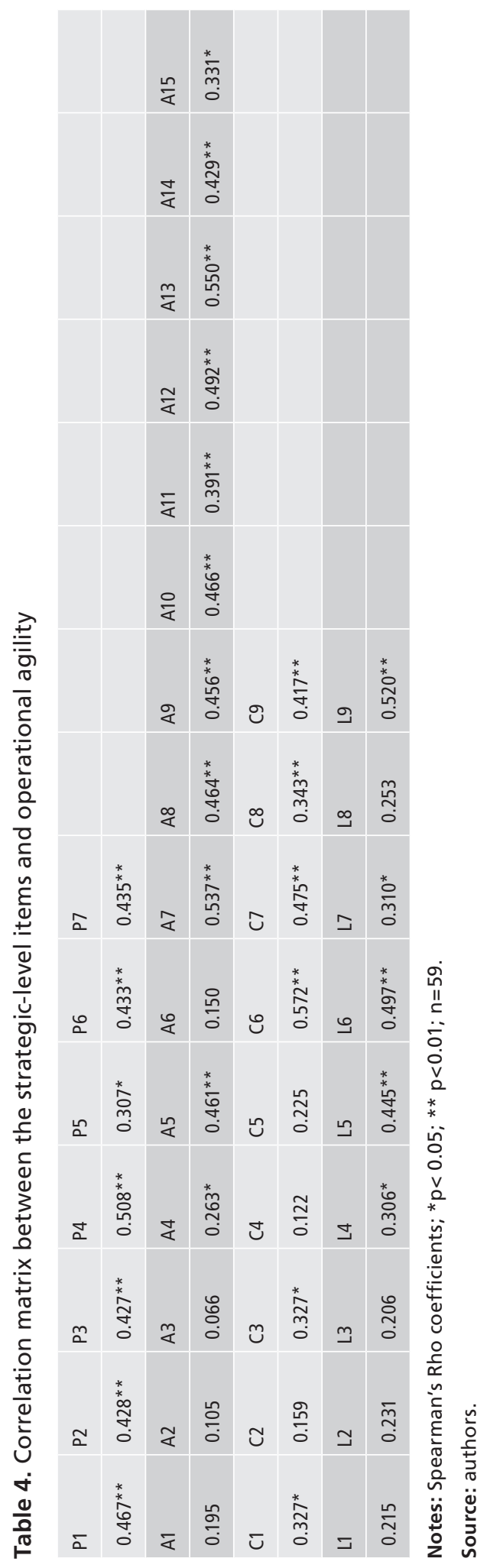


reflect all strategic-level capabilities, the correlation analysis confirms that the four capabilities play a role in the development of agility - a finding confirmed by the structural equation analysis in the next section.

\section{Strategic-level indicators}

Considering the item validities of a scale - that is, the level of correlation between each item and the outcome variable — and using this information to make decisions about which items to retain or delete, increases the predictive validity of the scales in relation to the outcome variable, as argued by Lounsbury, Gibson, and Saudargas (2006). To enhance the validity of the research, therefore, the study used the 22 aforementioned items (those showing the highest level of correlation with operational agility) to develop the scales for the four strategic-level indicators.

The study followed the previous approach to test the reliability of these scales. The Cronbach's alphas were $\alpha=0.803$ for being purposeful, $\alpha=0.880$ for being actionfocused, $\alpha=0.822$ for being collaborative, and $\alpha=0.765$ for being learning-oriented. However, a closer examination of the statistics revealed that the relative Cronbach's alphas of two scales (being purposeful and being action-focused) could have been improved if the following two items were discarded:

- P7: partners across the supply chain share a sense of common purpose; and

- Ar4: partners across the supply chain actively engage in information-sharing.

Since doing so would not have improved the consistency of the two scales significantly, and as the two items are considered to be neither ambiguous nor irrelevant to the rest of the scale items, they were both retained in their respective scales. In addition, the corrected item-to-total correlation levels are adequate for the four strategic-level scales, confirming the internal reliability of these scales and supporting the computation of composite scores. Consequently, the study aggregated the items and created composite measures for the four strategic-level capabilities. Altogether the five composite indicators computed (operational agility and the four strategiclevel capabilities) form the basis for the structural equation analysis undertaken below.

\section{Testing the hypothesised relationships Data examination and preparation}

The assumptions of structural equation modelling were tested to ensure the robustness of the analysis. Among these-to make sure that 'careless responses' were not included in the survey data (Meade and Craig, 2012) - a multivariate outlier analysis was conducted by using the Mahalanobis distance, which is designed to detect unusual combinations of scores (Allen, Bennett, and Heritage, 20I4). This yielded a maximum score of I8.467. Since the maximum Mahalanobis distance calculated for the cases in the data set was 10.458 (that is, below the critical value), the conclusion was 
that the data were free of multivariate outliers and, thus, free of 'careless responses'.

In addition, the level of normality in the distribution of the data was assessed by calculating the skewness and kurtosis statistics (see Table 5), and by considering the graphical representations of the five composite measures previously computed. This revealed that the data in respect of being purposeful were skewed. To normalise the data, the scores were mathematically transformed by using the LOGIo transformation method recommended by Tabachnick and Fidell (2007). Table 5 contains the descriptive statistics for the five constructs of this research, as well as the sample correlations.

\section{Structural equation modelling}

Structural equation modelling and the maximum likelihood estimation method of IBM SPSS Amos $22.0^{3}$ were used to test both the first hypothesis (related to the construct validity of organisational capacity building) and the second hypothesis (regarding the structural relationship between organisational capacity building and operational agility). Table 6 presents the results of this analysis. In particular, the estimates (four factor loadings and one path coefficient), their respective standard errors, and their measures of significance (t) are reported.

The t-values of the four factor loadings exceed I.96 and have a level of significance below the o.oor level. This confirms that being purposeful, being action-focused, being collaborative, and being learningoriented appropriately reflect organisational capacity building. In addition, as illustrated in Figure 2, each indicator has a strong standardised factor loading ranging

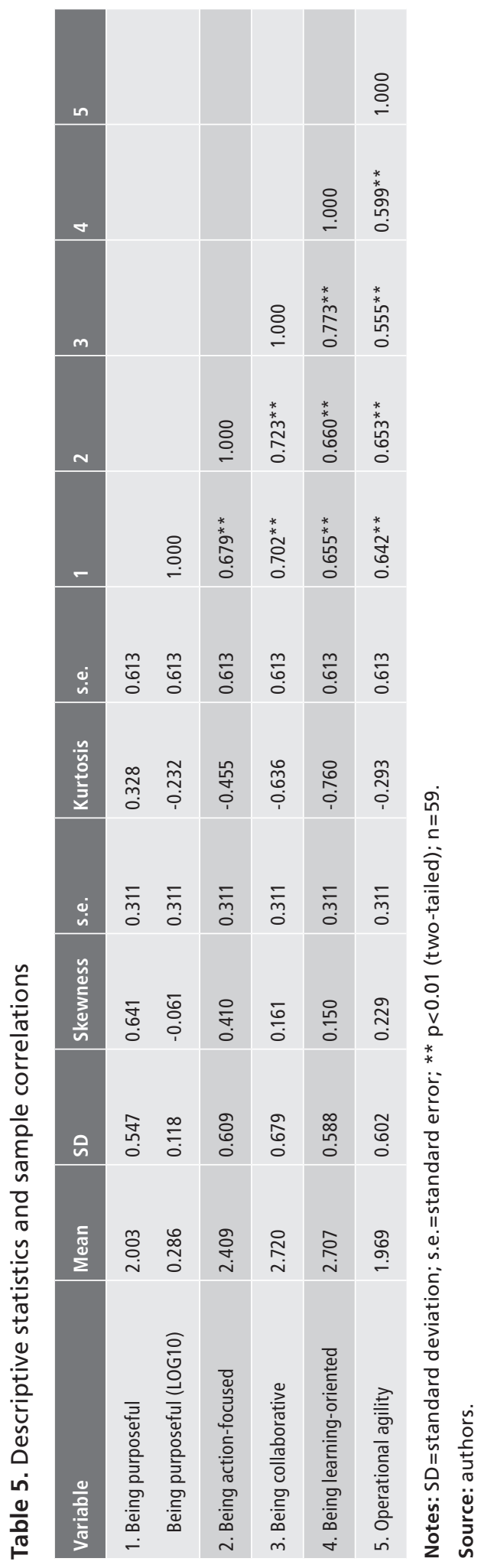


Table 6. Model output

\begin{tabular}{|c|c|c|c|c|}
\hline & Estimate & $\begin{array}{l}\text { Standard } \\
\text { error }\end{array}$ & $\begin{array}{l}\text { Measure of } \\
\text { significance (t) }\end{array}$ & $\begin{array}{l}\text { Standardised } \\
\text { estimate }\end{array}$ \\
\hline \multicolumn{5}{|l|}{ Factor loadings } \\
\hline Being purposeful $\leftarrow$ Organisational capacity building & 0.095 & 0.013 & $7.332^{* * *}$ & 0.813 \\
\hline Being action-focused $\leftarrow$ Organisational capacity building & 0.501 & 0.066 & $7.556^{* * *}$ & 0.830 \\
\hline Being collaborative $\leftarrow$ Organisational capacity building & 0.587 & 0.072 & $8.157^{* * *}$ & 0.871 \\
\hline Being learning-oriented $\leftarrow$ Organisational capacity building & 0.488 & 0.064 & $7.660 * * *$ & 0.837 \\
\hline \multicolumn{5}{|l|}{ Path coefficient } \\
\hline Organisational capacity building $\rightarrow$ Operational agility & 0.430 & 0.070 & $6.165^{* * *}$ & 0.721 \\
\hline
\end{tabular}

\section{Notes:}

$* * * \mathrm{p}<.001$.

$\chi^{2}=7.985$ for 5 DF and a $p$-value of $0.157 ; \chi^{2} / D F=1.597 ; \mathrm{SRMR}=0.032 ; \mathrm{GFI}=0.950 ; \mathrm{CFI}=0.983 ; \mathrm{RMSEA}=0.101$. $\left(\mathrm{DF}=\right.$ degrees of freedom; $\chi^{2} / \mathrm{DF}=$ normed chi-square; $\mathrm{SRMR}=$ standardised root mean square residual; $\mathrm{GFI}=$ goodness-of-fit index; and $\mathrm{CFI}=$ comparative fit index.)

$\mathrm{n}=59$.

Source: authors.

from $0.8 \mathrm{I}$ to 0.87 , providing clear indications of the significant relationships between the four strategic-level capabilities and organisational capacity building. In other words, the four strategic-level capabilities are appropriate measures of the underlying construct. Furthermore, as organisational capacity building accounts for the shared variance among the four indicators, these results demonstrate that the strategic-level capabilities are not only strongly related to organisational capacity building, but also are to one another.

The direct path from organisational capacity building to operational agility was also found to be positive and statistically significant. The standardised coefficient of 0.72 provides evidence that increasing organisational capacity building has a substantial impact on increasing operational agility. This is confirmed by the squared multiple correlation associated with operational agility (obtained by squaring the path coefficient, that is, $0.72^{2}=0.52$ ), indicating that organisational capacity building accounts for 52 per cent of the variance in operational agility. This clearly demonstrates that operational agility is significantly influenced by the strategic-level dimensions.

The goodness-of-fit indices reported in Table 6 show that the model provides a good fit to the data. In particular, the chi-square $\left(\chi^{2}\right)$ statistic of 7.985 with five degrees of freedom (DF) and a p-value of 0.I57, that is, greater than 0.05 , indicates that the model is operating adequately. Other fit indices, notably the normed chi-square $\left(\chi^{2} / \mathrm{DF}\right)$, the standardised root mean square residual (SRMR), the goodness-of-fit index (GFI), and the comparative fit index (CFI), are also within the commonly accepted standards reported by Schumacker and Lomax (20I0). While the root mean square error of approximation (RMSEA) is high (greater than o.o8), Browne and Cudeck 
Figure 2. Structural equation model's standardised estimates

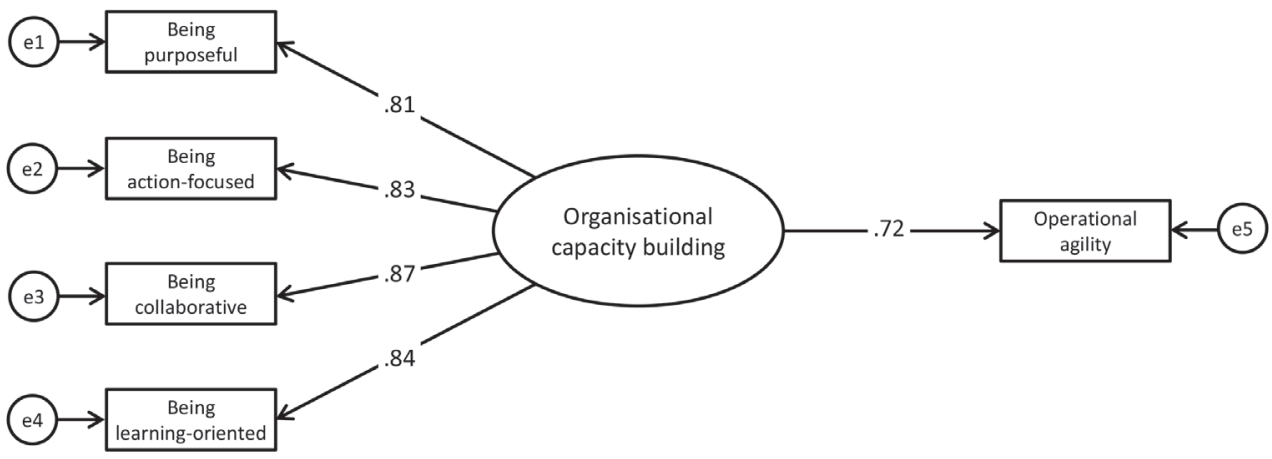

Notes: all standardised residual covariances are less than 0.5 .

Source: authors.

(I992) consider that a statistic below a O.I threshold is still acceptable, whereas Byrne (20IO) asserts that a high RMSEA value may lead to the rejection of a true model if the sample size is small (as is the case for the sample size of this research).

Overall, the findings validate the hypothesised model and confirm the multidimensional and multi-level nature of agility in a humanitarian logistics context. In other words, an agile organisation not only exhibits various characteristics (it is purposeful, action-focused, collaborative, learning-oriented), but also builds agility at all levels of the organisation (beyond the operational level).

\section{Discussion}

The results support the two hypotheses previously formulated. In particular, the data support the first hypothesis: that being purposeful, being action-focused, being collaborative, and being learning-oriented jointly reflect organisational capacity building and play a collective role in the creation of agility. One can conclude, therefore, that agility is not derived from one particular driver but rather from a combination of strategic-level forces that are closely intertwined and must be developed simultaneously. The second hypothesis, related to the positive impact of organisational capacity building on operational agility, is also validated. This confirms that agility transcends operations and stems from the close interactions of the strategic and the operational levels of a humanitarian organisation.

These results are consistent with research conducted in a number of management fields. For example, this study's findings on the positive role of purpose in achieving agility confirm the research on agile project management, which highlights that a clear mandate, a shared vision, and a value-driven culture trigger meaningful operational results (Appelo, 20I I). The results pertaining to the positive contribution of being action-focused with regard to operational agility also are in line with the work undertaken by a number of management authors (see, for example, Redding and 
Catalanello, I994). They argue that building a constant state of readiness is critical to organisations operating in turbulent environments because it enhances their ability to manage and overcome proactively and reactively risks and uncertainties. In particular, the findings are consistent with studies performed in the field of emergency management. Somers (2009), for instance, contends that local autonomy is necessary to deal with complexity, and that it leads to increased flexibility and quicker responses. Emergency management situations also require organisations to achieve adequate information and resource allocation, and to prepare people to become problem-solvers (Dynes, I994).

The positive influence of collaboration on supply chain agility found in this research also supports previous studies conducted in commercial (see, for example, Christopher, 2OII; Gligor and Holcomb, 20I2) and humanitarian (see, for example, Tatham and Christopher, 20I4; Saavedra and Knox-Clarke, 2015) contexts by demonstrating that sustaining internal and external relationships and working together are essential to deal with complexity and turbulence and to carry out smooth supply chain activities. In addition, the study findings support existing research on organisational learning, since intra- and inter-agency learning has long been recognised as critical to improving operations and to adapting to the multiple and ongoing disruptive forces encountered in the humanitarian environment (Van Brabant, I997; Ramalingam, Scriven, and Foley, 2009).

The originality of the work, though, is that it combines the four strategic-level capabilities into a single framework and, by so doing, demonstrates that organisational capacity building positively affects operational agility. In other words, the four strategiclevel capabilities are empirically confirmed as strategic antecedents of operational agility in humanitarian logistics. Going one step further, the study is the first in the humanitarian logistics literature to quantify the impact of organisational capacity building on operational agility, that is, to provide evidence that 52 per cent of the ability of fieldworkers to manage swiftly and appropriately supply chain contingencies depends on strategic-level forces. The other 48 per cent might be explained by operational drivers such as postponement (Oloruntoba and Gray, 2006) or the prepositioning of supplies (Beamon and Balcik, 2008), as well as by external factors such as the capacity of airports/seaports to handle increased volumes of cargo and/or the ability of national authorities to escort humanitarian convoys to avoid pilferage (L'Hermitte, Tatham, and Bowles, 20I4). Clearly these elements are important, but this study does not explore them in greater detail because they have already been documented in the humanitarian logistics literature and do not constitute the focus of the current paper.

Rather, the focus of this research is to emphasise that operational expertise is not sufficient to achieve supply chain agility. In other words, to be agile, a humanitarian organisation should not only develop logistics expertise (such as in warehousing, fleet management, and shipping), but also it should supplement these operational skills with a higher-level ability to respond to change and challenges. Doing so is essential not 
only because humanitarian organisations need to respond to multiple complexities and dynamics existing in field operations, but also because they have to be able to shift easily from one operation to another and to adapt swiftly to a new set of operational circumstances. Hence this research underlines the importance of building organisational capacity to maintain a certain level of performance while adapting to both short-term challenges and over-time changes.

The main contribution of this study is to assess empirically and quantitatively the impact of organisational capacity building on field-level agility and, consequently, to provide evidence that researchers and practitioners need to embrace a more comprehensive perspective of agility in humanitarian logistics. Going one step further, it provides a way forward for the development of organisational capacity by translating the capabilities into operating reality and supplying a list of practical and actionable elements (see Table 2) that leaders of humanitarian organisations can consider to create purposeful, action-focused, collaborative, and learning-oriented organisations.

In doing so, this paper lays the foundations of a new theory of agility in humanitarian logistics, that is, it not only establishes and quantifies the relationship between organisational capacity building and operational agility, but also it explains how organisational capacity building can be developed. According to Christensen and Carlile (2009), understanding/measuring a phenomenon of interest and explaining the causes leading to the outcome reflect the descriptive and prescriptive facets of theory building. Such a theory-building approach is essential because the humanitarian research is in need of sound theoretical frameworks that not only promote further research, but also inform practice (Jahre, Jensen, and Listou, 2009; Dijkzeul, Hilhorst, and Walker, 20I3).

\section{Limitations}

Four limitations should be considered in relation to this research. First, perception measures, rather than objective measures, were collected. According to Conway and Lance (20IO), it is important to explain why measuring perceptions is appropriate in the framework of a particular research investigation. Although some authors, such as Beamon and Balcik (2008), Davidson (2006), and McGuire (20II), have developed quantitative measures of performance in the field of humanitarian logistics, these measures might only be useful to evaluate the performance of a specific operation or to compare operations in similar environments. In other words, they might not be applicable to the overall operational performance of an organisation because the circumstances of each operation are specific and different. For instance, the evaluation of delivery times provides different results in different environments because operations differ in terms of the distances travelled, the condition of the infrastructure along the supply chain, and/or the topography of the affected areas. For this reason, subjective measures based on the perceptions of experts and on their overall experience 
in humanitarian logistics operations are more appropriate with respect to the research undertaken in this paper. Most importantly, the survey participants were specialists in humanitarian logistics with extensive experience (approximately 54 per cent of the respondents have been working in humanitarian logistics for more than Io years, and an additional 27 per cent for 6-Io years). This not only suggests that the subjective respondents' responses may align with objective measures, but also this increases the validity and reliability of the research.

Second, given that the purpose of this research is to investigate the strategic antecedents of agility in humanitarian logistics, the strategic-level constructs (that is, the four capabilities) are studied in greater detail than the operational components of agility. In other words, the number of items measuring responsiveness and flexibility is limited as compared to the number of items measuring the four strategiclevel capabilities.

Third, the relatively small sample size of this research should be considered. The structural equation model presented in Figure 2 includes Io parameters to be estimated (four factor loadings, one path coefficient, and the five error variances of the composite indicators). Since a number of authors, such as Bentler and Chou (1987) and Kline (2005), consider that 5 -IO cases per estimated parameter is appropriate (in particular when factor loadings are strong, as is the case in this research), the study's sample size of 59 cases seems adequate. However, a ratio of 5.9 cases per estimated parameter clearly is at the lower end of the 5-Io range. In addition, it has been argued repeatedly in the literature that structural equation modelling requires a large sample size (see, for example, Hair et al., 2006), and that the model estimates and the goodnessof-fit statistics may be underestimated or overestimated by an insufficient number of cases (see, for example, Wolf et al., 2013). Further studies should attempt, therefore, to increase the sample size when replicating/refining this research.

Fourth, since the survey participants were not recruited directly, no overview of the population is available for this study. Hence, the response rate is unknown and it is not possible to determine if the sample size is statistically representative of the population. For increased control of the survey data, future research could consider replicating this study within a single organisation or a number of specific organisations.

Notwithstanding the aforementioned research limitations, this paper confirms the relevance of a systems approach to the concept of agility, as explained further in the next section.

\section{Conclusions and implications}

This study adopts a systemic view of agility to investigate how strategic efforts and the development of an agile system can help humanitarian organisations better anticipate, adapt to, and overcome field-level contingencies. More specifically, it examines the nature of the strategic support needed by field logisticians to deal swiftly with disruptive forces, to eliminate/mitigate the negative impacts of such events, and to leverage the benefits of positive changes. 
Strategic factors have been recognised already as being critical to humanitarian logistics operations (Pettit and Beresford, 2009) and to the development of agility (Tatham and Christopher, 20I4), but the extent to which they contribute to the creation of agility has been unclear to date. This study attempts to remedy this deficiency and, thereby, extends the work already conducted on agility in the humanitarian logistics discipline. To achieve this, it tested empirically the impact of four strategiclevel capabilities (being purposeful, being action-focused, being collaborative, and being learning-oriented) on operational agility and established that the ability of field logisticians to be fully responsive and flexible depends on the capacity of the strategic level of their organisations to create an enabling environment.

Consequently, the investigation is not only valuable for researchers, but also for practitioners. In particular, it is anticipated that this study will help humanitarian organisations and their leaders to recognise that agility is a multidimensional concept and to understand better how to manage field-level complexities and dynamics. Agility stems from the interplay between multiple strategic drivers and involves focusing simultaneously on a variety of instruments in an active, systematic, and consistent manner. In other words, agility is not related to a particular isolated practice, but is embedded in an integrated system, the ultimate objective of which is to support fieldworkers and, thereby, achieve the seamless delivery of humanitarian supplies.

Most importantly, agility starts at the highest level of a humanitarian organisation and requires a system-wide and aligned approach that includes the way the organisation is structured, instils a sense of purpose, makes decisions, assigns responsibility, allocates resources, manages information, develops policies, connects the different parts of the organisation together, collaborates with other organisations, learns from experience, and processes knowledge. Thus, agility is fundamentally strategic. Since the four strategic-level capabilities collectively explain 52 per cent of operational agility, it is essential that the leaders of humanitarian organisations have a clear understanding of what should be done. To this end Table 2 provides a list of specific elements that can guide them in making decisions on how to support fieldworkers in overcoming disruptive forces. This pool of actions defines the four capabilities at a level of detail not previously seen in the humanitarian logistics literature, and provides the basis for a clear line of concrete activities that will enhance their achievement.

The list of items in Table 2 also confirms that people, processes, and technology are essential agility enablers (L'Hermitte et al., 20I5). Humanitarian organisations, therefore, need to develop their resources and make investments in a number of areas, including information technology and skills. For instance, making timely and accurate logistics information available requires the use of a track-and-trace information system. Along the same lines, sharing best practices throughout the organisation and across operations requires expertise in the development of collective and participatory projects that will bring together field logisticians and encourage them to share their experiences in a real-time and interactive environment.

In addition to highlighting the importance of technology and skills, Table 2 also points to the need to establish appropriate structures and processes to support responsive and flexible field operations. For example, suitable processes are essential for dealing 
with common field situations. Appropriate decision-making processes are also needed to support swift action.

The list of items in Table 2 is designed, therefore, to make the leaders of humanitarian organisations aware of the variety of mechanisms underlying the development of the four capabilities and, ultimately, the building of agility. However, the level of achievement of each of these items will, inevitably, differ from one organisation to another. This is because each organisation is different, and because not all organisations have reached the same level of agility and/or have emphasised the same mechanisms to develop their agility. As a result, it is recommended that the 40 strategic-level items included in Table 2 are considered individually by each organisation in order to determine which of them has been achieved already, and which need to be developed further. This will help humanitarian organisations to assess the reality of their current performance in terms of agility and the attainment of the four capabilities.

In particular, these 40 elements can be used and operationalised to answer the following questions:

- Does the executive level of the organisation recognise the four strategic-level capabilities as essential?

- Is there general acceptance at all levels of the organisation that these capabilities have to be developed?

- Are policies and processes in place to measure and assess the achievement of these capabilities?

- What is the organisation's level of achievement of each of the items presented in Table 2?

- What are the areas of improvement?

- Are policies, processes, and actions in place to fill the gaps?

These questions clearly demonstrate that building agility is a slow and ongoing process, and that a long-term and culturally-oriented perspective is needed. In particular, building agility requires a change in behaviour, that is, a shift in what individuals at all levels of the organisation do, as well as in the way that they think and work. In other words, agility is inherently cultural and building it is a shared responsibility. Most notably, developing agility requires a deliberate approach and the commitment of the leadership team that has responsibility for building the agile system that supports the operational level of the organisation. It is essential, therefore, that the leaders of humanitarian organisations listen to those in the field, understand their needs visà-vis responsiveness and flexibility, explore the extent to which field staff are provided with the appropriate tools, and develop the necessary strategic drivers. The participation of frontline workers is also critical as they need to search actively for new ways of doing things and improving practices, and actively share their experiences to contribute to the development of the whole organisation.

Doing so will enable humanitarian organisations to move from ad hoc creativity to internal capacity building in order to respond to the multiple field contingencies 
and to adapt to changing operational environments. This is all the more important as humanitarian crises have become more complex and dynamic. This, in turn, requires that humanitarian organisations develop more structured anticipatory and adaptive capacities (Kent, 20II).

Since the academic study of agility in humanitarian logistics is still in its early stage, this research provides the basis for further investigation of the concept in a more systemic and integrated way, and for developing new theoretical propositions about what makes a humanitarian organisation an agile organisation.

\section{Acknowledgements}

We would like to thank Adrian van der Knaap, Katja Hildebrand and other staff members of the United Nations World Food Programme who gave of their time and provided assistance and expertise in relation to this study. We are also grateful to Mike Whiting from the Humanitarian Emergency Logistics Professionals Forum of the Chartered Institute of Logistics and Transport in the United Kingdom and to all the humanitarian logistics experts who completed the survey and/or helped us recruit additional participants. Many thanks too to Jeong Jin Yu from the University of Tasmania for his valuable insights into the structural equation model.

\section{Correspondence}

Cécile L'Hermitte, Lecturer, University of Waikato, Waikato Management School, Private Bag 3105, Hamilton 3240, New Zealand.

E-mail: cecile.1hermitte@waikato.ac.nz

\section{Endnotes}

I Cécile L'Hermitte is a Lecturer at the Waikato Management School, University of Waikato, New Zealand; Dr Benjamin Brooks is a Senior Research Fellow at the National Centre for Ports and Shipping Australian Maritime College, University of Tasmania, Australia; Marcus Bowles is an Adjunct Professor at the Centre for Regional and Rural Futures, Deakin University, Australia; and Peter H. Tatham is a Professor of Humanitarian Logistics at the Department of International Business and Asian Studies, Griffith Business School, Griffith University, Australia.

2 For further reference, the 29 interviews were analysed qualitatively in L'Hermitte et al. (2016).

3 See http://www-03.ibm.com/software/products/en/spss-amos (last accessed on Io November 20I6).

\section{References}

Allen, P., K. Bennett, and B. Heritage (2014) SPSS Statistics Version 22: A Practical Guide. Cengage Learning Australia, Melbourne.

Appelo, J. (201 I) Management 3.o: Leading Agile Developers, Developing Agile Leaders. Pearson Education, Upper Saddle River, NJ. 
Australian Civil-Military Centre (20I2) 'Same space - Different mandates'. May. http://www.redcross. org.au/files/II966_ACMC_Same-Space_DifferentMandates.pdf (last accessed on II November 20I6).

Beamon, B.M. and B. Balcik (2008) 'Performance measurement in humanitarian relief chains'. The International Journal of Public Sector Management. 2I (I). pp. 4-25.

Bennett, D.A. (200I) 'How can I deal with missing data in my study?'. Australian and New Zealand Journal of Public Health. 25(5). pp. 464-469.

Bentler, P.M. and C.-P. Chou (I987) 'Practical issues in structural modeling'. Sociological Methods Research. I6(8). pp. 78-II7.

Bontis, N., M.M. Crossan, and J. Hulland (2002) 'Managing an organizational learning system by aligning stocks and flows'. Journal of Management Studies. 39(4). pp. 437-469.

Browne, M.W. and R. Cudeck (I992) 'Alternative ways of assessing model fit'. Sociological Methods Research. 2I(2). pp. 230-258.

Byrne, B.M. (20I0) Structural Equation Modeling with AMOS. Taylor and Francis Group, New York, NY.

Chandra, C. and J. Grabis (2007) Supply Chain Configuration: Concepts, Solutions and Applications. Springer, New York, NY.

Charles, A., M. Lauras, and L. Van Wassenhove (2010) 'A model to define and assess the agility of supply chains: building on humanitarian experience'. International Journal of Physical Distribution and Logistics Management. 40(8-9). pp. 722-74I.

Christensen, C.M. and P.R. Carlile (2009) 'Course research: using the case method to build and teach management theory'. Academy of Management Learning and Education. 8(2). pp. 240-25I.

Christopher, M.G. (20II) Logistics and supply chain management. Pearson Education Limited, Harlow.

Churchill, G.A. (I979) 'A paradigm for developing better measures of marketing constructs'. Journal of Marketing Research. I6(I). pp. 64-73.

Conway, J.M. and Lance, C.E. (20I0) 'What reviewers should expect from authors regarding common method bias in organizational research'. Journal of Business and Psychology. 25(3). pp. 325-334.

Davidson, A.L. (2006) 'Key performance indicators in humanitarian logistics'. http://dspace.mit.edu/ handle/I72I.I/35540 (last accessed on II November 20I6).

Dijkzeul, D., D. Hilhorst, and P. Walker (2013) 'Introduction: evidence-based action in humanitarian crises'. Disasters. $37\left(\mathrm{~S}_{\mathrm{I}}\right)$. pp. SI-SI9.

Dove, R. (I996) 'Agile supply-chain management'. Automative Production. Io8(4). pp. I6-I7.

Dynes, R.R. (I994) 'Community emergency planning: false assumptions and inappropriate analogies'. International Journal of Mass Emergencies and Disasters. I2(2). pp. I4 I-I58.

Eisenhardt, K.M. (I989) 'Building theories from case study research'. The Academy of Management Review. I4(4). pp. 532-550.

Featherstone, A. (2OI4) 'Missed again: making space for partnership in the Typhoon Haiyan response'. http://reliefweb.int/sites/reliefweb.int/files/resources/missed-again-typhoon-haiyan-september20I4.pdf (last accessed on I November 20I6).

Garvin, D.A. (I993) 'Building a learning organization'. Harvard Business Review. July-August. pp. 78-9I.

Gatignon, A., L.N. Van Wassenhove, and A. Charles (20I0) 'The Yogyakarta earthquake: humanitarian relief through IFRC's decentralized supply chain'. International Journal of Production Economics. I26(I). pp. IO2-IIO.

Gligor, D.M. and M.C. Holcomb (2012) 'Antecedents and consequences of supply chain agility: establishing the link to firm performance'. Journal of Business Logistics. 33(4). pp. 295-308.

Goldman, S.L. and R.N. Nagel (I993) 'Management, technology and agility: the emergence of a new era in manufacturing'. International Journal of Technology Management. 8(I-2). pp. I8-38.

Gunasekaran, A. (I998) 'Agile manufacturing: enablers and an implementation framework'. International Journal of Production Research. 36(5). pp. I223-I247.

Hair, J.F., W.C. Black, B.J. Babin, R.E. Anderson, and R.L. Tatham (2006) Multivariate Data Analysis. Pearson Prentice Hall, Upper Saddle River, NJ. 
Handfield, R.B. and E.L. Nichols (2002) Supply Chain Redesign: Transforming Supply Chains into Integrated Value Systems. Pearson Prentice Hall, Upper Saddle River, NJ.

Handler Chayes, A., A. Chayes, and G. Raach (1997) 'Beyond reform: restructuring for more effective conflict intervention'. Global Governance. 3(2). pp. II7-I 45 .

Jahre, M., L.-M. Jensen, and T. Listou (2009) 'Theory development in humanitarian logistics: a framework and three cases'. Management Research News. 32 (II). pp. I008-I023.

Kent, R.C. (2011) 'Planning from the future: an emerging agenda'. International Review of the Red Cross. 93(884). pp. 939-963.

Kline, R.B. (2005) Principles and Practice of Structural Equation Modeling. Guilford Press, New York, NY.

Kruke, B.I. and O.E. Olsen (2OI2) 'Knowledge creation and reliable decision-making in complex emergencies'. Disasters. 36(2). pp. 212-232.

L'Hermitte, C., M. Bowles, P.H. Tatham, and B. Brooks (2015) 'An integrated approach to agility in humanitarian logistics'. Journal of Humanitarian Logistics and Supply Chain Management. 5(2). pp. 209-233.

L'Hermitte, C., P.H. Tatham, and M. Bowles (20I4) 'Classifying logistics-relevant disasters: conceptual model and empirical illustration'. Journal of Humanitarian Logistics and Supply Chain Management. 4(2). pp. I55-I78.

L'Hermitte, C., P.H. Tatham, M. Bowles, and B. Brooks (2016) 'Developing organisational capabilities to support agility in humanitarian logistics: an exploratory study'. Journal of Humanitarian Logistics and Supply Chain Management. 6(I). pp. 72-99.

Little, R.J.A. (I988) 'A test of missing completely at random for multivariate data with missing values'. Journal of the American Statistical Association. 83(404). pp. I198-I202.

Logistics Cluster (2013) 'The LET: an invaluable partnership'. I7 December. http://www.logcluster. org/blog/let-invaluable-partnership (last accessed on in November 20I6).

Lounsbury, J.W., L.W. Gibson, and R.A. Saudargas (2006) 'Scale development'. In F.T.L. Leong and J.T. Austin (eds.) The Psychology Research Handbook. Sage Publications, Thousand Oaks, CA. pp. I25-I 46.

Manuj, I. and J.T. Mentzer (2008) 'Global supply chain risk management'. Journal of Business Logistics. 29(I). pp. I33-I55.

McCann, J.E. and J.W. Selsky (2012) Mastering Turbulence: The Essential Capabilities of Agile and Resilient Individuals, Teams and Organizations. Jossey-Bass, San Francisco, CA.

McGuire, G. (20I I) Handbook of Humanitarian Health Care Logistics. http://www.humanitarianhealth carelogistics.com/index_htm_files/Handbook\%20of\%2oHumanitarian\%2oHealth\%20Care\% 2oLogistics.pdf (last accessed on I I November 20I6).

Meade, A.W. and S.B. Craig (20I2) 'Identifying careless responses in survey data'. Psychological Methods. I7(3). pp. 437-455.

Metcalfe, V., E. Martin, and S. Pantuliano (20I I) Risk in Humanitarian Action: Towards a Common Approach? HPG Commissioned Paper. January. http://www.odi.org/publications/5463-risk-common-actionhumanitarian-approach-management (last accessed on II November 20I6).

Oloruntoba, R. and R. Gray (2006) 'Humanitarian aid: an agile supply chain?'. Supply Chain Management. II (2). pp. IIS-I2O.

Pettit, S. and A. Beresford (2009) 'Critical success factors in the context of humanitarian aid supply chains'. International Journal of Physical Distribution and Logistics Management. 39(6). pp. 450-468.

Ramalingam, B., K. Scriven, and C. Foley (2009) 'Innovations in international humanitarian action'. ALNAP 8th Review of Humanitarian Action. Chapter 3. http://www.alnap.org/resource/5664.aspx (last accessed on II November 20I6).

Redding, J.C. and R.F. Catalanello (1994) Strategic Readiness: The Making of the Learning Organization. Jossey-Bass, San Francisco, CA.

Roth, A.V. (1996) 'Neo-operations strategy - Linking capabilities-based competition to technology'. In G.H. Gaynor (ed.) Handbook of Technology Management. McGraw-Hill, New York, NY. pp. 38.I-38.44. 
Saavedra, L. and P. Knox-Clarke (20I5) Working Together in the Field for Effective Humanitarian Response. Background paper for the 3oth ALNAP Annual Meeting, Berlin Germany, 3-4 March 20I5. http:// www.alnap.org/resource/I9489 (last accessed on II November 20I6).

Schumacker, R.E. and R.G. Lomax (2010) A Beginner's Guide to Structural Equation Modeling. Routledge, New York, NY.

Seal, A. and R. Bailey (2013) 'The 20I I famine in Somalia: lessons learnt from a failed response?'. Conflict and Health. 7(I). pp. 22-26.

Shahabi, K., A. Cusumano, and S. Sohonie (2015) 'Agility is within reach'. Strategy+Business. 79 (summer). http://www.strategy-business.com/media/file/oo3I6_Agility-Is_Within_Reach.pdf(last accessed on i n November 2016).

Somers, S. (2009) 'Measuring resilience potential: an adaptive strategy for organizational crisis planning'. Journal of Contingencies and Crisis Management. I7(I). pp. I2-23.

Streiner, D.L., G.R. Norman, and J. Cairney (2015) Health Measurement Scales: A Practical Guide to their Development and Use. Oxford University Press, Oxford.

Tabachnick, B.G. and L.S. Fidell (2007) Using Multivariate Statistics. Pearson Education, Boston, MA.

Tatham, P.H. and M.G. Christopher (20I4) 'Introduction'. In P.H. Tatham and M.G. Christopher (eds.) Humanitarian Logistics. Kogan Page, London. pp. I-I8.

Tomasini, R. and L. Van Wassenhove (2009) Humanitarian Logistics. Palgrave Macmillan, Basingstoke.

Van Brabant, K. (1997) Organisational and Institutional Learning in the Humanitarian Sector. http://www. alnap.org/pool/files/kvblearn.pdf (last accessed on I I November 20I6).

Vázquez-Bustelo, D., L. Avella, and E. Fernández (2007) 'Agility drivers, enablers and outcomes'. International Journal of Operations and Production Management. 27(I2). pp. I3O3-I332.

Warner, R.M. (2013) Applied Statistics: From Bivariate through Multivariate Techniques. Sage Publications, Thousand Oaks, CA.

Weick, K.E. and K.M. Sutcliffe (200I) Managing the Unexpected. John Wiley and Sons, San Francisco, CA. WFP (World Food Programme) (20I3a) 'The long journey to South Sudan'. 28 March. http://www. wfp.org/logistics/blog/blog/steering-ethiopia-corridor (last accessed on I I November 20I6).

WFP (20I3b) 'Running on a full tank in Yemen'. Io September. https://www.wfp.org/logistics/blog/ blog/running-full-tank-yemen (last accessed on I I November 20I6).

WFP (20I3c) 'Stories from the road'. 3I October. http://www.wfp.org/logistics/blog/blog/stories-road (last accessed on I I November 20I6).

WFP (2014) 'Creative logisticians work around bad weather in the Philippines'. 7 February. https:// www.wfp.org/logistics/blog/blog/creative-logisticians-work-around-bad-weather-philippines (last accessed on i November 20I6).

Wolf, E.J., K.M. Harrington, S.L. Clark, and M.W. Miller (2013) 'Sample size requirements for structural equation models: an evaluation of power, bias, and solution propriety'. Educational and Psychological Measurement. 73(6). pp. 913-934. 